\title{
UPAYA MENINGKATKAN HASIL KETETAMPILAN PASSING ATAS \\ DALAM PERMAINAN BOLA VOLI DENGAN MENGGUNAKAN BOLA STANDARD DAN TIDAK STANDARD PADA PESERTA DIDIK KELAS XI IPS 4 SMA NEGERI 1 OKU
}

\author{
Ning Antariningsih \\ SMA Negeri 1 Ogan Komering Ulu \\ ningantariningsih99@gmail.com
}

\begin{abstract}
ABSTRAK
Penelitian ini dilatar belakangi oleh masih rendahnya keterampilan passing atas bolavoli peserta didik di kelas XI IPS 4 di SMA Negeri 1 OKU. Penelitian ini bertujuan untuk mengetahui peningkatan apakah penggunaan bola standard dan tidak standard dapat meningkatakan keterampilan passing atas bolavoli pada siswa kelas XI IPS 4 SMA N 1 OKU. Penelitian ini adalah penelitian tindakan kelas (classroom action research) yang dilakukan secara kolaboratif dan partisipatif. Desain penelitian ini menggunakan Model Kurt Lewin dalam 2 siklus terdiri dari perencanaan, pelaksanaan \& observasi, dan refleksi. Sampel penelitian meliputi siswa kelas XI IPS 4 yang berjumlah 36 siswa di SMA Negeri OKU. Fokus penelitian adalah meningkatkan keterampilan passing atas. Teknik pengumpulan data melalui tes perbuatan. Teknik analisis data dilakukan secara deskriptif kualitatif dan kuantitatif. Hasil penelitian menunjukkan bahwa Keterampilan Passing Atas Bolavoli Menggunakan bola standard dan tidak standard Untuk Siswa Kelas XI SMA Negeri 1 OKU mengalami peningkatan, yaitu dari Hasil tes siklus I diperoleh sebanyak 13 siswa $(36,11 \%)$ tuntas belajar, dan 23 siswa atau 63,9\% belum tuntas belajar. Kemudian pada hasil tes siklus II menunjukkan 34 siswa $(94,6 \%)$ tuntas belajar dan 2 siswa atau $5,45 \%$ belum tuntas belajar. Dengan demikian dapat disimpulkan bahwa dengan menggunakan bola standard dan tidak standard dapat meningkatkan proses pembelajaran dan kemampuan atas bola voli siswa kelas XI IPS 4 SMA Negeri 1 OKU.
\end{abstract}

Kata Kunci: Passing Atas, Bola Standard dan Tidak Standard

\begin{abstract}
This research motivated by the still low passing skills of volleyball students in class XI IPS 4 in SMA Negeri 1 OKU. This study aims to determine whether the use of standard and nonstandard ball can improve passing skills on volleyball in class XI IPS 4 students of SMA N 1 OKU. This research is a classroom action research conducted collaboratively and participatively. The design of this study uses the Kurt Lewin Model in 2 cycles consisting of planning, implementation \& observation, and reflection. The research sample included 36 students of class XI IPS 4, totaling 36 students in OKU Public High School. The focus of research is to improve upon passing skills. Data collection techniques through deeds test. The data analysis technique was carried out in a descriptive qualitative and quantitative manner. The results showed that the Passing Skills of Volleyball Using standard and nonstandard balls For Grade XI Students of SMA Negeri 1 OKU had increased, namely from the results of the first cycle test obtained as many as 13 students (36.11\%) had finished learning, and 23 students or 63, 9\% have not yet finished studying. Then the results of the second cycle test showed 34 students (94.6\%) had finished learning and 2 students or 5.45\% had not finished learning. Thus, it can be concluded that using standard and nonstandard balls can improve the learning process and the ability of volleyball for grade XI IPS 4 students at SMA Negeri 1 OKU.
\end{abstract}

Keywords: Passing Over, Standard and Nonstandard Balls 


\section{PENDAHULUAN}

Olahraga yang bersifat fisik sangat membantu ketiga perkembangan tersebut. Contohnya olahraga bola voli. Perkembangan psikomotor didapat dari gerakan-gerakan bola voli yang sangat membutuhkan kekuatan fisik. Perekembangan kongitif didapatkan dari taktik yang diterapkan untuk mengalahkan lawan, dan perkembangan afektif didapat dari ketrampilan mengendalikan sifat egois agar mengutamakan kerjasama dalam tim tersebut. Pertumbuhan tubuh pada manusia normal akan terjadi seiring dengan bertambahnya umur. Pertumbuhan tubuh adalah salah satu tanda perkembangan psikomotor. Perkembangan psikomotor akan tampak dari fisik seseorang. Menurut Bloom dan Krathwohl (Arma Abdoellah dan Agusmanaji, 1994) “aspek psikomotor menyangkut jasmani, keterampilan motorik yang mengintegrasikan secara harmonis sistem syaraf dan otot-otot pendidikan jasmani yang dilakukan sejak dini merupakan awal pengembangan prestasi olah raga. Hal ini menunjukkan betapa pentingnya pembinaan pendidikan jasmani, baik melalui jalur sekolah maupun luar sekolah, yang harus dilakukan sejak usia muda. Perkembangan fisik anak-anak terbina oleh aktivitas fisik serta pengalaman dalam hidupnya sesuai dengan bertambah usia anak tersebut. Perkembangan fisik yang diikuti oleh perkembangan fungsi organ tubuh, peningkatan keterampilan gerak dan ketrampilan berpikir serta kemandirian mental, merupakan perkembangan anak menuju ke kedewasaan jasmani dan rohani. Untuk mendukung perkembangan psikomotor, kongitif dan afektif maka perlu adanya aktifitas positif.

Bola voli merupakan salah satu olahraga permainan yang memasyarakat di Indonesia. Banyaknya klub-klub bola voli yang ada di Indonesia serta diadakannya Pro Liga merupakan salah satu wujud perkembangan dan kemajuan olahraga bola voli di Indonesia. Bahkan di lembaga sekolah permainan bola voli merupakan salah satu cabang olahraga yang wajib diajarkan bagi peserta didik sekolah. Hal ini karena banyak manfaat yang diperoleh melalui permainan bola voli baik untuk perkembangan jasmani maupun rokhani. Banyak manfaat yang diperoleh melalui kegiatan bermain bola voli. Oleh karena itu membelajarkan permainan bola voli bagi peserta didik sekolah sangat penting agar ketrampilan jasmani dan rohkani peserta didik berkembangan dengan baik. Dengan berkembangnya ketrampilan jasmani dan rokhani akan mendukung pencapaian 
tujuan belajar. Sebagai langkah awal dalam membelajarkan permainan bola voli bagi peserta didik sekolah yaitu diajarkan macam-macam teknik dasar bermain bola voli. Hal ini dimaksudkan agar peserta didik menguasai macam-macam teknik dasar bola voli, sehingga akan mendukung penampilannya dalam bermain bola voli, bahkan dapat mempengaruhi menang atau kalahnya suatu tim dalam bertanding. Hal ini sesuai pendapat Soedarwo, Sunardi dan Agus Margono (1994: 6) bahwa: Teknik dasar bola voli harus betul-betul dikuasai terlebih dahulu guna dapat mengembangkan mutu prestasi bola voli. Penguasaan teknik dasar permainan bola voli merupakan salah satu unsur yang ikut menentukan menang atau kalahnya suatu regu di dalam suatu pertandingan di samping unsur-unsur kondisi fisik, taktik dan mental.

Menguasai macam-macam teknik dasar bola voli merupakan fundasi agar dapat bermain bola voli dengan baik dan benar. Adapun teknik dasar bermain bola voli yang harus dikuasai terdiri beberapa macam yaitu: (1) passing, (2) servis, (3) umpan, (4) smash, dan (5) bendungan (block).
Passing merupakan salah satu teknik dasar bola voli yang mempunyai konstribusi besar dalam permainan bola voli. Passing merupakan salah satu teknik dasar bola voli yang mempunyai peran penting untuk memberikan umpan agar dapat melakukan serangan. Dapat dikatakan, serangan (smash) dalam bola voli diawali dari passing. Berdasarkan cara pelaksanaannya passing bola voli dibedakan menjadi dua yaitu passing atas dan passing atas.

Passing atas merupakan salah satu teknik dasar bola voli yang memiliki pola gerakan yang cukup kompleks, jika dibandingkan dengan passing atas. Tidak setiap peserta didik mampu melakukan passing atas dengan baik. Hal ini karena para peserta didik sekolah pada umumnya belum menguasai teknik passing atas. Selain itu, para peserta didik biasanya merasa takut untuk melakukan passing atas.

Bagi peserta didik yang belum pernah bermain bola voli tidak mampu melakukan passing atas. Peserta didik yang tidak mampu melakukan passing atas disebabkan oleh beberapa faktor misalnya, merasakan bola cukup berat, takut cidera, tidak memiliki pengalaman bermain bola 
voli dan lain sebagainya. Menurut Rusli Lutan (1988: 322) bahwa, "Faktor-faktor yang mempengaruhi proses belajar motorik adalah kondisi internal, dan kondisi eksternal”.

Peralatan bermain bola voli (bola) merupakan faktor eksternal yang dapat memberikan pengaruh terhadap proses belajar passing atas bola voli. Bola yang dirasakan berat akan mengakibatkan rasa takut, bahkan dapat menimbulkan cidera sehingga peserta didik tidak mampu melakukan passing atas. Selain itu, peserta didik yang belum siap (tidak memiliki pengalaman bermain bola voli) akan mengalami kesulitan dalam belajar passing atas. Seperti dikemukakan Rusli Lutan (1988: 406) bahwa, "Beberapa alasan kegagalan pelaksanaan dalam proses belajar antara lain "(1) perasaan takut mengalami cidera, (2) disefiensi dalam kondisi atau kesiapan seperti kekuatan belum cukup".

\section{Permasalahan yang dihadapi} peserta didik dalam belajar passing atas terutama peserta didik yang merasa takut dengan berat bola menuntut guru berkreativitas untuk menciptakan kondisi belajar yang sesuai dengan kondisi peserta didik. Jika dalam pembelajaran passing atas peserta didik merasa berat dengan bola voli ukuran standart, guru dapat menggunakan bola yang lebih ringan dan secara bertahap ditingkatkan menggunakan bola voli ukuran standart. Kendala atau masalah yang dihadapi peserta didik dalam belajar passing atas hendaknya guru harus mampu mencari solusi yang tepat agar tujuan pembelajaran dapat tercapai. Rusli Lutan \& Adang Suherman (2000:76) berpendapat, "Lakukan modifikasi perlatan, apabila peralatan diduga sebagai penghambat keberhasilan". dihadapi peserta didik dalam belajar passing atas hendaknya guru harus mampu mencari solusi yang tepat agar tujuan pembelajaran dapat tercapai. Rusli Lutan \& Adang Suherman (2000:76) berpendapat, "Lakukan modifikasi perlatan, apabila peralatan diduga sebagai penghambat keberhasilan".

Dari penjelasan di atas dalam pelajaran pendidikan jasmani, olahraga dan kesehatan (penjasorkes) ditemukan beberapa masalah yang komplek pada saat proses pembelajaran passing atas di permainan bola voli. Berhubungan dengan tujuan umum pendidikan jasmani yakni mengembangkan keterampilan untuk melakukan aktivitas jasmani dan olahraga, maka penulis tertarik untuk melakukan 
penelitian dengan judul "Upaya Meningkatkan Ketrampilan passing atas dalam permainan bola voli dengan menggunakan bola standard dan tidak standard pada peserta didik kelas XI IPS 4 SMA Negeri 1 OKU".

Berdasarkan permasalahan di atas maka penulisan makalah ini bertujuan untuk mengetahui bahwa penggunaan bola standard dan tidak standars dapat meningkatkan ketrampilan teknik Passing atas dalam permainan bola basket pada peserta didik kelas XI IPS 4 SMA Negeri 1 OKU.

Slamet (2010:2), mendefinisikan belajar sebagai suatu proses usaha yang dilakukan individu untuk memperoleh perubahan tingkah laku yang baru secara keseluruhan, sebagai hasil pengalamannya sendiri dalam interaksi dengan lingkungannya. Menurut Gagne dan Berliner dalam Rifa ${ }^{e} i$ (2009:82), belajar merupakan proses di mana suatu organisme mengubah perilakunya karena hasil dari pengalaman. Lebih lanjut Gagne menyatakan bahwa belajar merupakan perubahan disposisi kecakapan manusia yang berlangsung dalam periode waktu tertentu dan perubahan perilaku itu tidak berasal dari proses pertumbuhan.
Permainan bola voli diciptakan oleh William G. Morgan pada tahun 1985 di kota Halyoke. Dia seorang guru pendidikan jasmani pada Young xxvii Men Christian Association (YMCA). Pembelajaran bolavoli disamping dapat meningkatkan pengetahuan peserta didik juga dapat menambah keterampilan. Permainan bolavoli sendiri merupakan jenis permainan yang menggunakan bola besar.

Bola voli adalah permainan diatas lapangan persegi empat yang lebarnya 900 $\mathrm{cm}$ dan panjang $1800 \mathrm{~cm}$ dibatasi oleh garis-garis selebar $5 \mathrm{~cm}$, di tengahtengahnya dipasang jaring yang lebarnya $900 \mathrm{~cm}$, terbentang kuat dan mendaki sampai $243 \mathrm{~cm}$ (khusus untuk putera) dan untuk puteri $224 \mathrm{~cm}$. (Bonnie Robinson, 1997:12).

Bola voli merupakan olahraga permainan yang sudah berkembang dan banyak digemari oleh masyarakat di Indonesia. Bolavoli merupakan olahraga permainan yang dalam pelaksanaannya bola dipantulkan sebelum bola menyentuh tanah. Dalam hal ini Aip Syarifuddin dan Muhadi (1991/1992: 183) menyatakan, "Bolavoli adalah suatu bentuk permainan yang termasuk dalam cabang olahraga 
permainan. Voli artinya pukulan langsung atau memukul bola langsung di udara sebelum bola jatuh ke tanah".

Pembelajaran passing atas menggunakan bola tidak satandart merupakan bentuk pembelajaran keterampilan yang dilakukan dari cara yang sederhana atau mudah. Hal ini karena peserta didik dalam kondisi belum siap atau bola dianggap sebagai penghambat dalam belajar passing atas bola voli. Adapun bola tidak standart yang dimaksud yaitu bola bola yang lebih ringan seperti plastik yang dilapisi kalep, bola tangan, bola lunak.

Pembelajaran passing atas bola voli menggunakan bola tidak standart merupakan suatu bentuk pembelajaran yang berorientasi untuk mengatasi kendala-kendala dalam pembelajaran keterampilan. Jika peserta didik mengalami kesulitan melakukan passing atas menggunakan bola standart, maka dapat dilakukan dari cara yang lebih mudah atau menggunakan bola yang lebih ringan. Rusli Lutan dan Adang Suherman (2000: 75\&76) menyatakan, "Manakala kondisi sebenarnya menjadi penghambat belajar keterampilan tertutup, rubahlah kondisi latihan itu pada tingkat yang bisa dilakukan peserta didik selama perubahan kondisi tersebut tidak merusak integritas skill yang dipelajarinya". Sedangkan ditinjau dari prinsip-prinsip pengaturan belajar keterampilan Sugiyanto (1996: 64) menyatakan:

Pembelajaran passing atas bola voli menggunakan bola standart merupakan bentuk belajar yang menekankan pada kesiapan kondisi peserta didik. Pada pembelajaran ini semua peserta didik dianggap telah siap dengan tugas ajar yang akan diberikan guru. Berat bola bukan merupakan kendala dalam proses belajar keterampilan passing atas. Sugiyanto \& Agus Kristiyanto (1998:2) menyatakan "Hukum kesiapan (law of readinees) menyatakan bahwa belajar akan berlangsung sangat efektif jika pelaku belajar berada dalam suatu kesiapan untuk memberikan respons". Menurut Rusli Lutan (1988: 126) menyatakan bahwa: Belajar akan berlangsung efektif jika peserta didik yang bersangkutan telah siap untuk memberikan respon. Hukum kesiapan adalah semacam hukum tentang kesiapan untuk menyesuaikan diri dengan stimulus. Dalam kegiatan belajar keterampilan motorik seperti dalam olahraga misalnya faktor kesiapan, faktor fisik yang berkaitan dengan kematangan 
fisik atau biologis akan mempengaruhi proses belajar.

Penelitian ini dilaksanakan di kelas XI IPS 4 SMA N 1 OKU, pada materi pelajaran bola voli. Waktu Pelaksanaan Penelitian Pelaksanaan penelitian ini dilakukan dalam waktu tiga bulan, yakni bulan Agustus sampai Oktober tahun pelajaran 2019/2020.

Untuk memperoleh suatu penelitian diperlukan suatu data yang terdiri dari subjek penelitian, seperti yang dikemukakan oleh Suharsimi (1991:102), ialah suatu subjek penelitian adalah keseluruhan objek penelitian yaitu berisi seluruh peserta didik. Penelitian ini adalah peserta didik kelas XI IPS 4 SMA N 1 OKU tahun pelajaran 2019/2020 dengan jumlah 36 peserta didik.

Dalam penelitian tindakan kelas ini terdapat 2 siklus dan setiap siklusnya terdiri dari 2 pertemuan, dimana setiap siklus terdiri dari 4 tahap yaitu perencanaan, tindakan/ perlakuan, observasi/ pengamatan, dan refleksi, Kedua siklus ini dilaksanakan dengan tujuan untuk mengetahui ada atau tidaknya peningkatan ketrampilan passing atas bola voli dengan menggunakan bola standard dan tidak standard.
Pada penelitian ini terdapat 2 siklus yang akan dilakukan, dalam setiap siklus terdiri dari 2 peretemuan. Setiap siklus terdapat empat tahap yang terdiri dari perencanaaan, tindakan/ perlakuan, observasi/ pengamatan dan refleksi.

\section{HASIL DAN PEMBAHASAN}

\section{Siklus I}

a. Perencanaan

Menyusun rencana pelaksanaan pembelajaran dan menyediakan media

b. Tindakan (Action)

Setelah siswa mempersiapkan diri di lapangan. Guru selanjutnya mengkondisikan siswa untuk menerima pelajaran kemudian melakukan apersepsi dengan mendeskripsikan teknik dasar passing atas dan menjelaskan dengan menggunakan contoh gerakan. Setelah melakukan apersepsi dan tanya jawab, guru menyampaikan tujuan pembelajaran yang akan dicapai siswa yaitu melakukan kegiatan passing atas. Guru menjelaskan langkah-langkah pembelajaran yang akan dilakukan siswa yaitu Pembelajaran Pendidikan Jasmani Kesehatan dengan pendekatan menggunakan bola standard dan tidak standard. Kemudian guru memberikan materi pemanasan dengan permainan nelayan menjaring ikan. Pada kegiatan akhir guru memberikan kegiatan 
pendinginan dengan permainan "sebut kata". Guru menutup pembelajaran dengan memberikan pesan agar melakukan latihan mandiri di rumah. Guru menutup pelajaran dengan berdoa.

c. Obervasi

Hasil observasi yang berupa aktivitas kegiatan siswa dan guru, peneliti akan memaparkan hasil belajar siswa berupa tingkat keterampilan passing atas.

Tabel 1. Analisis Keterampilan Passing Atas Siklus I

\begin{tabular}{lllll}
\hline No & Skor & Frekwensi & Persentase & Keterangan \\
\hline 1 & $70 \leq$ & 13 & $36,11 \%$ & Tuntas \\
& $\mathrm{X}$ & & & \\
\hline 2 & $\mathrm{X} \leq$ & 23 & $63,8 \%$ & $\begin{array}{l}\text { Belum } \\
\text { Tuntas }\end{array}$ \\
\hline & 70 & & & \\
\hline
\end{tabular}

Berdasarkan hasil siklus I tersebut, 13 siswa atau $36,11 \%$ siswa tuntas belajar dan 23 siswa atau $63,8 \%$ belum tuntas belajar. Data dari tabel di atas mengenai keterampilan passing atas siswa berdasarkan pada siklus I dapat diperjelas melalui diagram di atas ini:

\section{SIKLUS I}

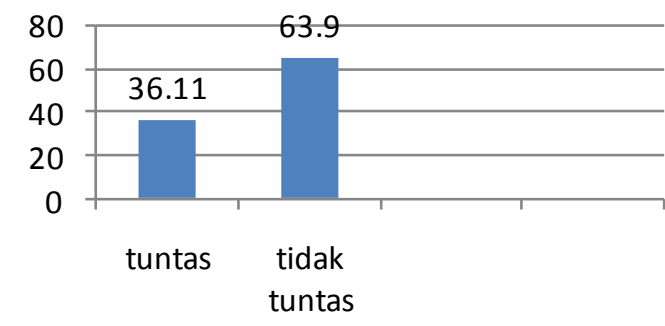

Diagram 1. Diagram Keterampilan Passing Atas siklus I

d. Refleksi

Kegiatan refleksi ini dimaksudkan sebagai bahan masukan pada perencanaan siklus selanjutnya. Refleksi pada siklus I dilakukan oleh peneliti. Tujuan dari kegiatan refleksi ini adalah untuk membahas hal hal apa saja yang menjadi hambatan pada pelaksanaan siklus I. Hal ini dikarenakan pada siklus I masih belum mencapai tingkat ketuntasan secara klasikal dengan ketuntasan minimal sebesar $85 \%$ atau 30 siswa tuntas. Akan tetapi, pada siklus I baru diperoleh 13 siswa tuntas belajar sehingga harus dilanjutkan ke siklus selanjutnya.

\section{Siklus II}

a. Perencanaan

Rencana pelaksanaan pembelajaran atau RPP disusun sebelum kegiatanpenelitian tindakan kelas dilaksanakan.

Peneliti mempersiapkan media gambar gerakan teknik dasar dan peralatan serta perlengkapan pembelajaran. Lembar penilaian keterampilan gerak siswa disusun oleh peneliti berkolaborasi dengan guru 
disesuaikan dengan pembelajaran Pendidikan Jasmani Kesehatan.

b. Tindakan

Setelah siswa mempersiapkan diri di lapangan. Guru selanjutnya mengkondisikan siswa untuk menerima pelajaran kemudian melakukan apersepsi dengan mendeskripsikan teknik dasar passing atas dan menjelaskan dengan menggunakan gambar. Setelah melakukan apersepsi dan tanya jawab, guru menyampaikan tujuan pembelajaran yang akan dicapai siswa yaitu melakukan kegiatan passing atas. Guru menjelaskan langkahlangkah pembelajaran yang akan dilakukan siswa yaitu Pembelajaran Pendidikan Jasmani Kesehatan dengan pendekatan bermain. Kemudian guru memberikan materi pemanasan dengan permainan nelayan menjaring ikan yang dikembangkan.

Pada kegiatan akhir guru memberikan kegiatan pendinginan dengan permainan "sebut kata". Guru menutup pembelajaran dengan memberikan pesan agar melakukan latihan mandiri di rumah. Guru menutup pelajaran dengan berdoa.

\section{c. Observasi}

Selain hasil observasi yang berupa aktivitas kegiatan siswa dan guru, peneliti akan memaparkan hasil belajar siswa berupa tingkat keterampilan passing atas

Tabel 2. Analisis Keterampilan Passing Atas Siklus II

\begin{tabular}{ccccc}
\hline No & Skor & $\begin{array}{c}\text { Frekwen } \\
\text { si }\end{array}$ & Persentase & Ket \\
\hline 1 & $70 \leq \mathrm{X}$ & 34 & $94,4 \%$ & Tuntas \\
& & & & \\
\hline 2 & $\mathrm{X} \leq$ & 2 & $5,6 \%$ & Belum \\
& 70 & & & Tuntas
\end{tabular}

Berdasarkan hasil siklus II tersebut, 34 siswa atau $94,4 \%$ siswa tuntas belajar dan 2 siswa atau 5,6\% belum tuntas belajar. Data dari tabel di atas mengenai keterampilan passing atas siswa berdasarkan pada siklus II dapat diperjelas melalui diagram di atas ini:

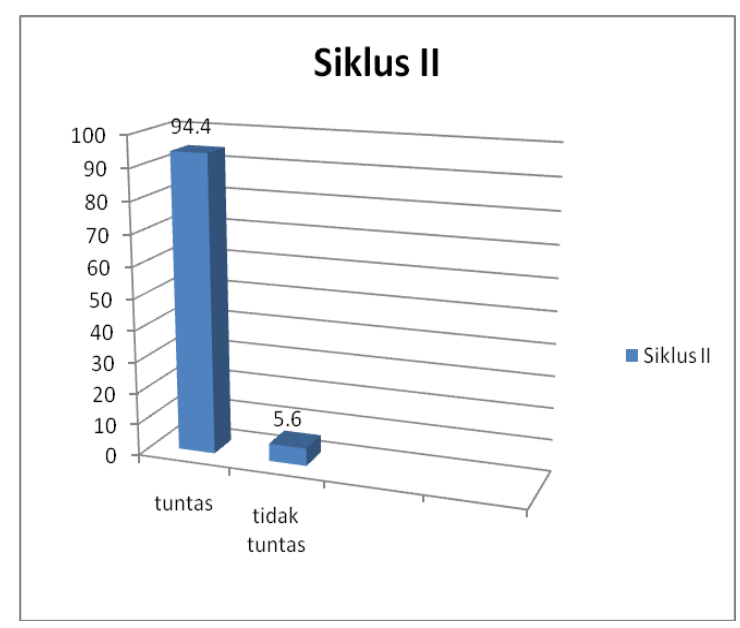

Diagram 2 . Diagram Keterampilan Passing Atas 


\section{Pembahasan}

Hasil dari indikator tersebut maka dibandingkan berdasarkan pada kategori keberhasilan yaitu $85 \%$ pada tingkat ketuntasan. Adapun perbandingannya sebagai berikut:

Tabel 3. Persentase perbandingan tingkat ketuntasan belajar pada siklus I dan siklus II

\begin{tabular}{ccc}
\hline Siklus & Tuntas & $\begin{array}{c}\text { Belum } \\
\text { tuntas }\end{array}$ \\
\hline I & $36,11 \%$ & $63,9 \%$ \\
\hline II & $94,4 \%$ & $5,6 \%$ \\
\hline
\end{tabular}

Berdasarkan tabel di atas dapat diketahui bahwa siklus II mengalami peningkatan dibandingkan dari siklus I pada ketuntasan

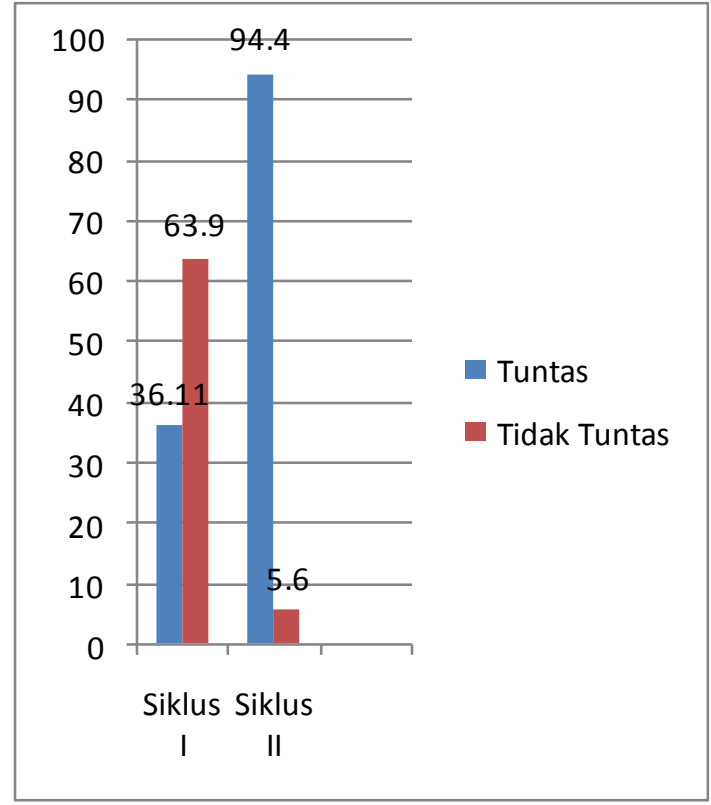

Diagram 3. Perbandingan kekuntasan belajar pada siklus I dan Siklus II
Berdasarkan data di atas dapat diketahui bahwa siklus II sebanyak 34 siswa atau $94,4 \%$ telah tuntas belajar dibandingkan data nilai siklus I 13 siswa atau $36,11 \%$, dan siklus II sebanyak 2 siswa atau $5,6 \%$ belum tuntas belajar dibandingkan data nilai siklus I, 23 siswa atau 63,9\%.

Berdasarkan hasil tersebut maka dapat disimpulkan bahwa penelitian ini telah mencapai indikator keberhasilan penelitian yaitu $85 \%$ siswa mempunyai ketuntasan belajar minimal pada kategori tuntas belajar, sehingga tidak perlu adanya tindakan lanjut pada siklus selanjutnya. Selain data di atas, dalam proses pembelajaran pendidikan jasmani kelas XI IPS 4 SMA Negeri 1 OKU ini juga diperoleh data observasi siswa terhadap pembelajaran yang telah dilakukan selama dua siklus. Di mana secara keseluruhan pembelajaran bolavoli materi teknik dasar passing atas melalui penggunaan bola standard dan tidak standard telah berjalan dengan sangat baik. Kegiatan pembelajaran dapat dinilai baik dari awal pembelajaran sampai dengan akhir pembelajaran. Siswa dapat bekerjasama dengan baik dengan teman lain untuk menyiapkan peralatan pembelajaran. Selain itu siswa dapat aktif, antusias dan 
bekerjasama antar teman dari pemanasan sampai permainan dilakukan dalam pembelajaran.

Kelebihan ini juga diperlihatkan pada guru di mana guru mampu memberikan kesempatan pada siswa untuk melakukan pertanyaan tentang apa yang anggap sulit sehingga siswa dapat mudah untuk memahami pembelajaran yang di sampaikan. Kegiatan refleksi ini dimaksudkan sebagai bahan masukan pada perencanaan siklus selanjutnya atau pembelajaran selanjutnya. Dari hasil pembelajaran siklus II ini telah idrasa cukup berhasil dikarenakan siswa telah mencapai ketuntasan belajar sebesar 94,11\%. Sebuah pembelajaran akan berjalan dengan lancar dan maksimal apabila tersedia sarana dan prasarana yang memadai dan materi ajar juga harus dikemas dan disampaikan dengan baik sehingga siswa dapat menemui kesulitan dan dapat memecahkan kesulitan tersebut melalui bimbingan dari guru. Sehingga perlu adanya pola interaksi yang baik antara siswa, guru dan sekolah. Di mana tersediannya sarana dan pengemasan pembelajaran yang menarik akan mampu memberikan hal positif bagi siswa.

\section{KESIMPULAN DAN SARAN}

Penelitian Tindakan Kelas yang berjudul "Upaya Meningkatkan Ketrampilan Passing Atas Dalam Permainan Bola Voli Dengan Menggunakan Bola Standard Dan Tidak Standard Pada Peserta Didik Kelas XI IPS 4 SMA Negeri 1 OKU”, menghasilkan kesimpulan sebagai berikut: Ketrampilan passing atas siswa mengalami peningkatan, yaitu dari Hasil tes siklus I diperoleh sebanyak 13 siswa $(36,11 \%)$ tuntas belajar, dan dan 23 siswa atau 63,9\% belum tuntas belajar. Kemudian pada hasil tes siklus II menunjukkan 34 siswa $(94,56 \%)$ tuntas belajar dan 2 siswa atau $5,4 \%$ belum tuntas belajar.

Dalam pembelajaran penjasorkes passing atas permainan bola voli, sebaiknya guru menggunakan pendekatan yang menarik dan mengaktifkan peserta didik sehingga selama proses pembelajaran peserta didik merasa senang dan bersemangat dalam belajar. Salah satu pendekatan yang dapat diimplementasikan yaitu penggunaan bola standard dan tidak standard. Guru diharapkan dapat memilih dan menerapkan metode serta media pembelajaran yang sesuai dengan materi pelajaran, sehingga keefektifan kegiatan belajar mengajar dapat tercapai dan 
suasana pembelajaran menjadi lebih menyenangkan.

\section{DAFTAR PUSTAKA}

Aip Syarifuddin dan Muhadi. 1991/1992. Pendidikan Jasmani. Jakarta: Depdikbud. Dirjendikti.Proyek Pembinaan Tenaga Kependidikan.

Arma Abdoellah dan Agusnaji.1994. Aspek -Aspek Yang Mempengaruhi Pendidikan. Jakarta: Depdiknas. Direktorat Jenderal Pendidikan Dasar dan Menengah.

Barbara L.V. \& Bonnie J.F. 1996. Bola voli Tingkat Pemula. Alih Bahasa. Monti. Jakarta: Raja Grafindo.

Rifa'i.2009. Belajar Dan Faktor keberhasilannya. Jakarta: Depdikbud Direktorat Jendral Pendidikan Tinggi.

Rusli Lutan. 1988. Belajar Ketrampilan Motorik Pengantar Teori dan Metode. Jakarta: Depdikbud. Dirjendikti.

Rusli Lutan dan Adang Suherman. 2000. Perancanaan Pembelajaran Penjaskes. Depdiknas. Direktorat Jenderal Pendidikan Dasar dan Menengah Bagian Proyek Penataran Guru SLTP Setara DIII.

Slameto. 2010. Belajar dan Faktor-Faktor yang Mempengaruhi. Jakarta: PT. Rineka Cipta.

Sugiyanto. 1996. Metodologi Penelitian. Surakarta: UNS Press.
Sugiyanto dan Agus Kristiyanto. 1998. Belajar Gerak II. Surakarta: UNS Press.

Soedarwo dan Sunardi. 1994. Kepelatihan Bola voli. Surakarta: UNS Press.

Suharsimi.1991. Classroom Action Research. Jakarta: Depdikbud Direktorat Jendral Pendidikan Tinggi. 